Copyright (C) 2016 by Academic Publishing House Researcher

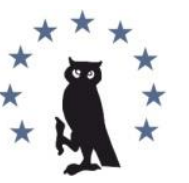

Published in the Russian Federation

European Researcher

Has been issued since 2010.

ISSN 2219-8229

E-ISSN 2224-0136

Vol. 107, Is. 6, pp. 330-338, 2016

DOI: 10.13187/er.2016.107.330

www.erjournal.ru

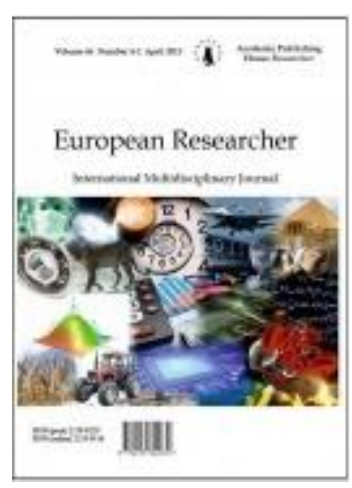

Pedagogical sciences

Педагогические науки

UDC 37

\title{
Willingness to Communicate Among Bosnian and Turkish Students at International University of Sarajevo
}

\author{
${ }^{1}$ Almasa Mulalic \\ ${ }^{2}$ Nudzejma Obralic
}

\author{
1-2 International University of Sarajevo, Bosnia and Herzegovina \\ ${ }^{1}$ Assistant professor, doctor \\ E-mail: amulalic@ius.edu.ba \\ ${ }^{2}$ Assistant professor, doctor \\ E-mail: obralicn@gmail.com
}

\begin{abstract}
This study examines the willingness to communicate, communication apprehension and communication competence among Turkish and Bosnian students at IUS. Willingness to communicate as defined by McCroskey and Richard (1987) means an individual personal's general personality orientation towards talking. Communication apprehension according to McCroskey (1984) is an individual level of fear or anxiety associated with either real or anticipated communication with other person or persons. Communication competence according to McCroskey and McCroskey (1986) is ones people's perception of his/her communication competence. Data for this study was collected from students enrolled in freshman classes at IUS. Survey method was used to collect data from the participants using questionnaires. T-test was used to analyze data for this study for all measures (WTC, PRCA, and SPCC) in order to determine the difference in willingness to communicate, communication apprehension and communication competence among Bosnian and Turkish students. The results of this study showed that there is no statistically significant difference between Turkish and Bosnian students regarding their willingness to communicate. However, the results showed that there are differences among Bosnian and Turkish students regarding their communication apprehension. The results also showed that there is difference between Bosnian and Turkish students regarding communication competence. However, the results did not show any statistically significant difference between Turkish and Bosnian students regarding student's willingness to communicate, communication apprehension and communication competence.
\end{abstract}

Keywords: willingness to communicate (WTC); communication apprehension (PRCA); communication competence (SPCC) and international university of Sarajevo. 


\section{Introduction}

Willingness to communicate contributes to both language learning and language acquisition. Therefore, Dörnyei (2005) argues that "it is not uncommon to find people who tend to avoid entering L2 communication situations even if they possess a high level of communicative competence" (p. 207). Since communication is a crucial part of L2 acquisition, MacIntyre and Charos (1996) explain that the primary reason for language learning often is aimed at using of language for basic communicate purposes. No matter for what purpose the language learning might be, (e.g., meeting new people, traveling, experiencing other cultures, or even using language in one's job) people use language to convey the message and communicate their ideas and opinions.

Individual learners' differences influence second language learning, motivation, aptitude, language learning styles and strategies. Therefore, many studies have been completed on language learning and teaching which has already established the importance of individual differences (IDs) in second language acquisition (SLA) (Andreou, Andreou, \& Vlachos, 2004, 2006; Andreou \& Galantomos, 2009; Andreou, Vlachos, \& Andreou, 2005, 2006; Dörnyei, 2005, 2009). These researchers elaborated on how individual differences play an important role in successful second language acquisition. According to Dörnyei, (2005) individual differences (IDs) refer to characteristics, which differentiate individuals from each other in terms of their acquiring of a particular language. In the same manner, Andreou et. al. (2006) argue that the way people learn and acquire the language depend on individual differences. Regarding the importance of individual differences and its relatedness to successful language acquisition researchers turned to other variables related to personality and individual differences. Therefore, individual differences (IDs) depend on willingness to communicate (WTC), communication apprehension (CA), and communicative competence (SPCC). The novelty of this research depends on successful examination of the relationship between these variables.

McCroskey and Bear (1985) proposed willingness to communicate (WTC) as the construct in the trait-like personality that people reveal when communicating in their first language. In this regard, willingness to communicate is closely related to L2 learners' psychological readiness to initiate communication (MacIntyre \& Charos, 1996; MacIntyre, Clément, Dörnyei, \& Noels, 1998). Then, McCroskey (1970 and 1977) defines communication apprehension (CA) as "an individual's level of fear or anxiety associated with either real or anticipated communication with another person or persons" (p. 78). The most widely used and accepted measure of communication apprehension (CA) has been McCroskey's (1982) Personal Report of Communication Apprehension-24 (PRCA-24) scale. According to the scale there are four different contexts of CA such as interpersonal, meeting, group and public. Interpersonal CA is the level of fear or anxiety associated with either real or anticipated communication with another individual in a one-on-one interaction. In essence, if someone experiences anxiety while thinking about interacting with another person or during an actual interaction with another person, he/she is said to have interpersonal CA. Meeting and group CA type, examine the level of fear or anxiety associated with either real or anticipated communication with another person(s) during a meeting/classroom environment. Every individual type of CA is contextually related to a meeting or a small group situation. Lastly, public CA is the level of fear or anxiety associated with either real or anticipated communication with another person(s) during a formal speaking situation. The last type of CA is probably closest aligned with the research conducted in social phobia discussed earlier. However, each of these four contexts is highly related with one another (Beatty, McCroskey, \& Heisel, 1998). Communicative competence is very important in one's life and for that reason, good communication needs to be learned and practiced. Hymes (1966) introduced communicative competence and later on, many other researchers redefined the concept based on Hymes' ideas. Hymes argued that speakers of a language have to have more than grammatical competence in order to be able to communicate effectively.

Based on the above discussion regarding the research problem and the significance the main objectives of this research are:

a. Is there any difference among Bosnian and Turkish students regarding their willingness to communicate?

b. Is there any difference between Bosnian and Turkish students in regards to communication apprehension? 
c. Is there any difference among Bosnian and Turkish students in regards to their communication competence?

d. Is there any difference in student's willingness to communicate, communication apprehension and communication competence among male and female students?

\section{Literature Review}

McCroskey (1985) introduced the construct "willingness to communicate" in relation to communication in the native language. His study included introversion, self-esteem, communication competence, communication apprehension and cultural diversity as antecedents of WTC. Moreover, this study argued that any kind of generalization on willingness to communicate need to be elaborated with the reference to culture. Different cultural backgrounds of the people play a decisive role in willingness to communicate and eventually in language acquisition.

MacIntyre (1994) hypothesized that communication apprehension and perceived competence influence the WTC. On the other hand, introversion is associated to both communication apprehension and perceived competence while self-esteem is related to communication apprehension. Based on his model, people are willing to communicate when they are not apprehensive about communication and when they perceive themselves as capable of communicating effectively.

MacIntyre and Charos (1996) extended the structural model by adding motivation, personality, the frequency of communication and context as predictors of WTC. They hypothesized that WTC and integrative motivation would explain the frequency of communication in L2.

MacIntyre et. al. (1998) integrated linguistic, communicative and social psychological variables to explain one's WTC in his/her second language. However, they treated WTC in L2 as a situational variable that has both transient and enduring influences. Moreover, they theorized that WTC influences speaking, listening, writing and reading modes. A pyramid shaped figure is used to illustrate the WTC model. A pyramid model demonstrates the wide variety of factors that affect the psychological preparedness to speak. Both individual factors (anxiety, motivation, attitudes, interpersonal attraction, etc.) and social contextual factors (ethno linguistic vitality, language contact, etc.) either enhance or reduce WTC (MacIntyre, 2007).

Hashimoto (2002) studied Japanese ESL students in classroom context as to test affective variables as predictors of reported second language use. He showed that motivation and WTC affect reported L2 communication frequency in classroom. Perceived competence and L2 anxiety were found to be causes of WTC, which led to more L2 use and L2 anxiety was found to negatively influence perceived competence. Although a path from WTC to motivation was not found as significant in the original study, it was found to be significant in the present research replication. In addition, a path from perceived competence was found to exert a strong and direct influence on motivation from a data-driven path.

Kang (2005) noted how situational willingness to communicate (WTC) in a second language (L2) can dynamically emerge and fluctuate during a conversation situation. He found that situational WTC in L2 emerged from the joint effect of three interacting psychological conditions of excitement, responsibility and security. Each was co-constructed by interacting situational variables such as topic, interlocutors, and conversational context. Based on the findings, he proposed a multilayered construct of situational WTC and a new definition of WTC in L2. Accordingly, WTC is proposed as a dynamic situational concept that can change moment-tomoment, rather than a trait-like predisposition. He also presented pedagogical implications, suggesting ways in which situational variables can be controlled to create L2 learners' situational WTC.

Cetinkaya (2005) in an investigation of Turkish college students' willingness to communicate in English as a foreign language found that students' willingness to communicate was directly related to their attitude towards the international community and their perceived linguistic selfconfidence. Furthermore, motivation and personality in terms of being an introvert or extrovert were found to be indirectly related to students' willingness to communicate through linguistic selfconfidence. Finally, he found that students' attitude toward the international community was correlated with their personality.

Zarrinabadi and Abdi (2011), in their investigation of the relationship between Iranian EFL learners' willingness to communicate (WTC) inside and outside the classroom and their language 
learning orientations, found that language orientations are more correlated with willingness to communicate outside than inside the classroom.

Baghaei (2012) on the relationship between willingness to communicate in learning English as a foreign language showed that two out of the three subscales of WTC (willingness to communicate in the school context and willingness to communicate with native speakers of English) were moderately correlated with success in learning English as a foreign language.

Numerous studies have concluded that those who experience communication apprehension or low self-esteem will withdraw from communication, thus affecting their willingness to communicate. McCroskey and Richmond (1987) were addressing communication apprehension caused by fear, anxiety and the thought of negative consequences to speaking. When discussing communication apprehension, many people assume it revolves around public speaking. Communication apprehension does affect public speaking outcomes, but it also affects the willingness to communicate in many different contexts. For example, according to Graen, Dansereau and Minami (1972), the relationship quality between a superior and subordinate can be determined by the quality of their communication exchanges. Previous research has shown communication apprehension is associated with fear of anticipated communication (McCroskey, 1977).

\section{Research Methodology}

This is a quantitative research with the aim to identify differences among Bosnian and Turkish students regarding their willingness to communicate. The second objective aims to determine differences between Bosnian and Turkish students about communication apprehension. The third objective will determine differences among Bosnian and Turkish students concerning their communication competence. The research design for this study is a quantitative with the survey method. According to Wiersma (2000), the survey method is used to measure variables that are related to a phenomenon without questioning why these variables exist. In this research, the instrument is a set of questionnaires is used to obtain the information from the students (sample). According to Wiersma (2000), the identification of a research population is important as it determines the type of problem for investigation. Population for this research is the 79 freshman students at International University of Sarajevo. According to Sakaran (2000), for a population of $\mathrm{N}=800$, a sample of $\mathrm{n}=175$ can be used to represent a generalization. In this study the research respondents attended three classes of Freshman English I (79 students) and responded to the questionnaire.

All respondents received a set of questionnaire consisting of a demographic questionnaire and adopted McCroskey's Personal Report Communication Apprehension (PRCA). This instrument uses five point Likert scale type response formats and the reliability is very high at above alpha $=0.90$ in most cases. The most recently developed 24-item version of the instrument includes six items for each of four contexts: public speaking, speaking in formal meetings, speaking in small group discussions and interpersonal interaction. This version also permits the generation of four sub-scores as well as an overall score. The independent variables are the four sub-scores and the dependent variable is overall score. Respondents respond to the 24 items by choosing the number on a 5-point Likert-type scale from 1 (strongly agree), 2 (agree), 3 (neither agree nor disagree), 4 (disagree) and 5 (strongly disagree).

The second set of questions was instrument that measures a person's willingness to initiate communication (Willingness to Communicate Questionnaire). The face validity of the instrument is strong, and results of extensive research indicate the predictive validity of the instrument. Alpha reliability estimates for this instrument have ranged from .85 to well above .90. (McCroskey, 1992).

Self-Perceived Communication Competence Scale (SPCC) was also administered in this research. The self-perceived communication competence scale was developed to obtain information concerning how competent people feel in a variety of communication contexts and with a variety of types of receivers. Early self-report measures of competence were structured to represent what the creators of the measures felt were the components of communication competence. This scale is intended to let the respondent define communication competence. Since people make decisions with regards to communication (for example, whether they will even do it), it is their perception that is important, not that of an outside observer. This measure has generated good alpha reliability estimates (above .85) and had strong face validity. It also has been found to have substantial predictive validity. 


\section{Data Presentation and Analysis}

To analyze the data SPSS for windows was used. Descriptive statistics, reliability score and T-test was used to examine the research questions.

Question 1: Is there any statistically significant difference among Bosnian and Turkish students regarding their willingness to communicate?

\begin{tabular}{|l|c|c|c|}
\hline \multicolumn{1}{|c|}{ Nationality } & Mean & N & Std. Deviation \\
\hline Bosnian & 76,41 & 56 & 11,241 \\
\hline Turkish & 75,04 & 23 & 9,393 \\
\hline Total & 76,01 & 79 & 10,694 \\
\hline
\end{tabular}

Table 1. t-test

\begin{tabular}{|c|c|c|c|c|c|c|c|c|c|}
\hline & $\begin{array}{l}\text { Levene's } \\
\text { Test for } \\
\text { Equality } \\
\text { of } \\
\text { Variances } \\
\end{array}$ & $\begin{array}{l}\text { t-test for } \\
\text { Equality } \\
\text { of } \\
\text { Means } \\
\end{array}$ & & & & & & & \\
\hline & $\mathrm{F}$ & Sig. & $\mathrm{t}$ & $\mathrm{df}$ & $\begin{array}{l}\text { Sig. (2- } \\
\text { tailed) }\end{array}$ & $\begin{array}{c}\text { Mean } \\
\text { Difference }\end{array}$ & $\begin{array}{l}\text { Std. Error } \\
\text { Difference }\end{array}$ & $\begin{array}{c}95 \% \\
\text { Confidence } \\
\text { Interval of } \\
\text { the } \\
\text { Difference } \\
\end{array}$ & \\
\hline $\begin{array}{l}\text { Equal } \\
\text { variances }\end{array}$ & & & & & & & & Lower & Upper \\
\hline assumed & 2,893 & ,093 & ,514 & 77 & 609 & 1,367 & 2,661 & $-3,932$ & 6,666 \\
\hline $\begin{array}{l}\text { Equal } \\
\text { variances } \\
\text { not } \\
\text { assumed }\end{array}$ & & & ,554 & 48,747 & ,582 & 1,367 & 2,468 & $-3,594$ & 6,328 \\
\hline
\end{tabular}

According to the table above t-test did not show that there is any difference between Bosnian and Turkish students in their willingness to communicate. Therefore, it can be stated that both Bosnian and Turkish students do not have problems with regard to an initiation of the conversation. Even though students are coming from different educational and cultural backgrounds, there was no statistically significant difference in their willingness to communicate.

Question 2: Is there any statistically significant difference between Bosnian and Turkish students regarding their communication apprehension?

\begin{tabular}{|c|c|c|c|c|}
\hline Nationality & $\mathrm{N}$ & Mean & Std. Deviation & Std. Error Mean \\
\hline Bosnian & 56 & 74,68 & 5,970 & .798 \\
\hline Turkish & 23 & 78,39 & 12,706 & 2,649 \\
\hline
\end{tabular}

Table 2. t-test

\begin{tabular}{|c|c|c|c|c|c|c|c|c|c|}
\hline & $\begin{array}{l}\text { Levene's Test } \\
\text { for Equality } \\
\text { of Variances }\end{array}$ & $\begin{array}{l}\text { t-test for } \\
\text { Equality } \\
\text { of Means }\end{array}$ & & & & & & & \\
\hline & $\mathrm{F}$ & Sig. & $\mathrm{t}$ & $\mathrm{df}$ & $\begin{array}{l}\text { Sig. (2- } \\
\text { tailed) }\end{array}$ & $\begin{array}{l}\text { Mean } \\
\text { Differ } \\
\text { ence }\end{array}$ & $\begin{array}{c}\text { Std. } \\
\text { Error } \\
\text { Differe } \\
\text { nce }\end{array}$ & $\begin{array}{c}95 \% \\
\text { Confidence } \\
\text { Interval of } \\
\text { the } \\
\text { Difference }\end{array}$ & \\
\hline Equal & & & & & & & & Lower & Upper \\
\hline assumed & 12,454 & ,001 & $-1,772$ & 77 & , 080 & $-3,713$ & 2,095 & $-7,885$ & ,460 \\
\hline Equal & & & $-1,342$ & 26,085 & ,191 & $-3,713$ & 2,767 & $-9,399$ & 1,974 \\
\hline
\end{tabular}




\begin{tabular}{|l|l|l|l|l|l|l|l|l|l|}
\hline $\begin{array}{l}\text { variances } \\
\text { not } \\
\text { assumed }\end{array}$ & & & & & & & & & \\
\hline
\end{tabular}

Table 2 shows difference (Sig., o01) between Bosnian and Turkish students regarding communication apprehension. Here, Turkish students showed that they have some kind of fear or anxiety in using the language. Perhaps identified difference needs further research studies on students' language background. Turkish students generally were not exposed to English language throughout their primary and high school education. Majority of them had to go through English Language School and pass English language Proficiency test at the International University of Sarajevo (IUS). On the other hand, Bosnian students were exposed to English language on the daily basics, through TV and other media.

Question 3: Is there any statistically significant differences among Bosnian and Turkish students in regards to their communication competence.

\begin{tabular}{|c|c|c|c|c|}
\hline Nationality & $\mathrm{N}$ & Mean & Std. Deviation & Std. Error Mean \\
\hline Bosnian & 56 & 74,68 & 5,970 &, 798 \\
\hline Turkish & 23 & 78,39 & 12,706 & 2,649 \\
\hline
\end{tabular}

Table 3. t-test

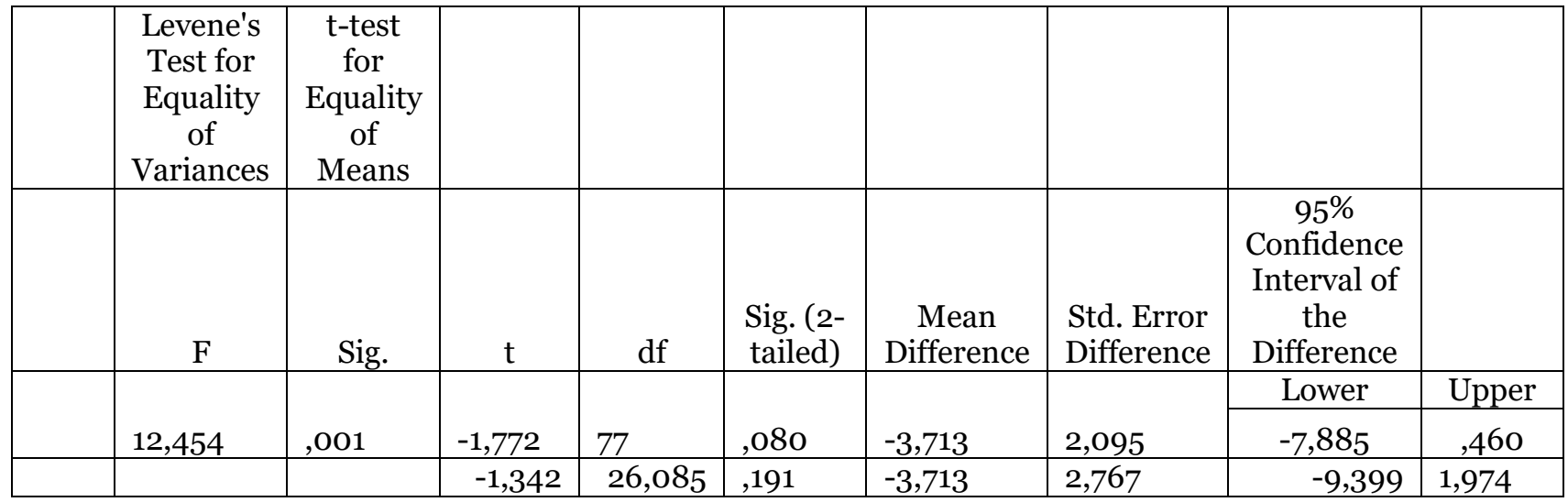

Table 3 shows statistically significant difference between Bosnian and Turkish students regarding communication competence. Turkish students did not feel very confident and competent to use English language in comparison to Bosnian students. Therefore, the results show that Turkish students perceived themselves as not competent enough when using English language. Again, this feeling can be traced to their past encounter with the use of English language throughout their education.

Question 4: Is there any statistically significant difference in student's willingness to communicate, communication apprehension and communication competence among male and female students? 
Table 4. Male female differences

\begin{tabular}{|l|l|r|r|r|r|}
\hline & Gender & N & \multicolumn{1}{c|}{ Mean } & \multicolumn{1}{c|}{$\begin{array}{c}\text { Std. } \\
\text { Deviation }\end{array}$} & \multicolumn{1}{c|}{$\begin{array}{c}\text { Stror } \\
\text { Mean }\end{array}$} \\
\hline & male & 42 & 77,88 & 9,446 & 1,458 \\
\hline $\begin{array}{l}\text { Communication } \\
\text { apprehension }\end{array}$ & female & 37 & 73,35 & 6,820 & 1,121 \\
\hline $\begin{array}{l}\text { Willingness to } \\
\text { communicate }\end{array}$ & male & 42 & 73,95 & 11,436 & 1,765 \\
\hline & male & 37 & 78,35 & 9,396 & 1,545 \\
\hline $\begin{array}{l}\text { Communication } \\
\text { competence }\end{array}$ & female & 42 & 45,60 & 8,425 & 1,300 \\
\hline
\end{tabular}

Table 5. T-test for the male female differences

\begin{tabular}{|c|c|c|c|c|c|c|c|c|}
\hline & $\begin{array}{l}\text { Levene's } \\
\text { Test for } \\
\text { Equality } \\
\text { of } \\
\text { Varianc } \\
\text { es }\end{array}$ & $\begin{array}{l}\text { t-test } \\
\text { for } \\
\text { Equa } \\
\text { lity } \\
\text { of } \\
\text { Mea } \\
\text { ns }\end{array}$ & & & & & & \\
\hline & $\mathrm{F}$ & Sig. & $\mathrm{t}$ & $\mathrm{df}$ & $\begin{array}{c}\text { Sig. } \\
(2- \\
\text { tailed) }\end{array}$ & $\begin{array}{c}\text { Mean } \\
\text { Difference }\end{array}$ & $\begin{array}{l}\text { Std. Error } \\
\text { Difference }\end{array}$ & $\begin{array}{c}95 \% \\
\text { Confidence } \\
\text { Interval of } \\
\text { the } \\
\text { Difference } \\
\end{array}$ \\
\hline \multirow{2}{*}{$\begin{array}{l}\text { Communication } \\
\text { apprehension }\end{array}$} & \multirow{2}{*}{2,691} & \multirow{2}{*}{,105 } & 2,414 & & \multirow{2}{*}{$\begin{array}{l}018 \\
\text {,016 }\end{array}$} & \multirow{2}{*}{$\begin{array}{l}4,530 \\
4,530\end{array}$} & Lower & Upper \\
\hline & & & 2,463 & 74,263 & & & 1,876 & ,793 \\
\hline \multirow[t]{2}{*}{$\begin{array}{l}\text { Willingness to } \\
\text { communicate }\end{array}$} & 1,477 & ,228 & $\begin{array}{r}- \\
1,853 \\
\end{array}$ & 77 & ,068 & $-4,399$ & 1,839 & ,866 \\
\hline & & & $1,876^{-}$ & 76,651 & ,064 & $-4,399$ & 2,375 & $-9,127$ \\
\hline \multirow[t]{3}{*}{$\begin{array}{l}\text { Communication } \\
\text { competence }\end{array}$} & , 039 & ,844 &,- 696 & 77 & ,488 & $-1,324$ & 2,345 & $-9,069$ \\
\hline & & &,- 696 & 75,713 & ,488 & $-1,324$ & 1,901 & $-5,109$ \\
\hline & & & & & & & 1,901 & $-5,111$ \\
\hline
\end{tabular}

Table 5 indicated that there is no statistically significant difference among male and female students regarding student's willingness to communicate, communication apprehension and communication competence.

\section{Conclusion}

Communication situations are often important for the communicator. Then, apprehension in second language use reflects a situational basis related to the number of persons with whom the person is communicating. In the literature, researchers are talking about principally three methods of reducing anxiety about communication events: skill training, cognitive modification and systematic desensitization. Anxiety is common trait among most people who are engaged in any kind of communication exchange and especially people who reluctantly accept public exposure and speaking. In order for students to feel less anxious and more comfortable in using the second language in different circumstances skill training is required. Instructors in collaboration with the other relevant personnel from the institution should engage students in skill training and cognitive thinking as to overcome communication problems. 
The result of this study showed that there is no statistically significant difference between Turkish and Bosnian students regarding their willingness to communicate. However, the results showed that there are differences among Bosnian and Turkish students regarding communication apprehension. In this research, Turkish students felt more anxious in communicating in English language. The results also showed that there is difference between Bosnian and Turkish students regarding the communication competence. Turkish students felt less competent in comparison to Bosnian students regarding using of English language in different circumstances. However, the results did not show any statistically significant difference between Turkish and Bosnian students regarding student's willingness to communicate, communication apprehension and communication competence.

\section{References:}

1. Andreou, E., Andreou, G., \& Vlachos, F. (2004). Studying orientations and performance on verbal fluency tasks in second language. Learning and Individual Differences. 15, 23-33.

2. Andreou, G., Andreou, E., \& Vlachos, F. (2006). Individual differences in second language learning among university students. In S.N. Hogan (Ed.), Trends in learning research (pp. 81-99). New York: Nova Science Publishers.

3. Andreou, G., \& Galantomos, I. (2009). The native speaker ideal in FLT. Electronic Journal of Foreign Language Teaching. 6(2), 200-208.

4. Andreou, E., Vlachos, F., \& Andreou, G. (2005). Affecting factors in second language learning. Journal of Psycholinguistic Research. 34(5), 429-438.

5. Andreou, E., Vlachos, F., \& Andreou, G. (2006). Approaches to studying among Greek university students: The impact of gender, age, academic discipline and handedness. Educational Research. 48(3), 301-311.

6. Baghaei, P. (2012). The relationship between willingness to communicate and success in learning English as a foreign language. Modern Journal of Applied Linguistics. 4(2), 53-67.

7. Beatty, M. J., McCroskey, J. C., \& Heisel, A.D. (1998). Communication apprehension as temperamental expression: A communibiological paradigm. Communication Monographs. 65, 197-219.

8. Cetinkaya, Y. B. (2005). Turkish college students' willingness to communicate in English as a foreign language. (Unpublished doctoral dissertation). Ohio: The Ohio State University.

9. Dörnyei, Z. (2005). The psychology of the language learner: Individual differences in second language acquisition. Mahwah, NJ: Lawrence Erlbaum.

10. Dörnyei, Z. (2009). The L2motivational self system. In Z. Dörnyei, \& E. Ushioda (Eds.), Motivation, language identity and the L2 self (pp. 9-42). Bristol: Multilingual Matters.

11. Hashimoto, Y. (2002). Motivation and willingness to communicate as predictors of reported L2 use: The Japanese ESL context. Second Language Studies. 20(2), 29-70.

12. MacIntyre, P.D., Clément, R., Dörnyei, Z., \& Noels, K.A. (1998). Conceptualizing willingness to communicate in a L2: A situated model of confidence and affiliation. Modern Language Journal. 82, 545-562.

13. MacIntyre, P. D., \& Charos, C. (1996). Personality, attitudes, and affect as predictors of second language communication. Journal of Language and Social Psychology. 15(1), 3-26.

14. McCroskey, J.C., \& Baer, J.E. (1985). Willingness to communicate: The construct and its measurement. Paper presented at the Annual Convention of the Speech Communication Association, Denver, Colorado.

15. McCroskey, J. C. (1992). Reliability and validity of the willingness to communicate scale (WTC). Communication Quarterly. 40, 16-25.

16. McCroskey, J. C. (1970). Measures of communication-bound anxiety. Speech Monographs. 37, 269-277.

17. McCroskey, J. C. (1977). Oral communication apprehension: A summary of recent theory and research. Human Communication Research. 4, 78-96.

18. McCroskey, J. C. (1982). An introduction to rhetorical communication (4th Ed). Englewood Cliffs, NJ: Prentice-Hall.

19. McCroskey, J.C., \& Richmond, V.P. (1987). Willingness to communicate and interpersonal communication. In J.C. McCroskey, \& J.A. Daly (Eds.), Personality and interpersonal communication (pp. 129-156). Beverly Hills, CA: Sage. 
20. McCroskey, J.C., \& McCroskey, L.L. (1988). Self-report as an approach to measuring communication competence. Communication Research Reports. 5(2), 108-113.

21. Zarrinabadi, N., \& Abdi, R. (2011).Willingness to communicate and language learning orientations in Iranian EFL context. International Education Studies. 4(4), 206-214.

\title{
УДК 37
}

\section{Готовность к общению среди боснийских и турецких студентов в Международном университете Сараево}

\author{
${ }^{1}$ Алмаса Мулалик \\ ${ }^{2}$ Нудзейма Обралик
}

\author{
1-2 Международный университет Сараево, Босния и Герцеговина \\ ${ }^{1}$ Доктор наук, доцент \\ E-mail: amulalic@ius.edu.ba \\ 2 Доктор наук, доцент \\ E-mail: obralicn@gmail.com
}

Аннотация. Данное исследование рассматривает готовность к коммуникационным взаимодействиям, осмыслению информации и коммуникативной компетентности среди турецких и боснийских студентов МУС. Готовность к общению, как определяют ученые Макроки и Ричард (1987), определяется общей индивидуальной ориентации личности к разговору. Данные для этого исследования были собраны среди студентов, обучающихся на первом курсе в МУС. Метод опроса был использован для сбора данных от участников при помощи анкетирования. Т-тест был использован для анализа данных исследования (WTC, PRCA и SPCC), чтобы определить разницу в готовность к общению, коммуникационной компетентности среди боснийских и турецких студентов. Результаты этого исследования показали, что нет статистически значимых различий между турецкими и боснийскими студентами относительно их готовности к общению. Однако результаты показали, что существуют различия между боснийскими и турецкими студентами относительно их проблем в общении. Результаты также показали, что существует разница между боснийскими и турецкими студентами в их коммуникативной компетентности. Однако результаты не показали каких-либо статистически значимых различий между турецкими и боснийскими студентами в готовности студентов к общению, боязни общения и коммуникативной компетентности.

Ключевые слова: готовность общаться (WTC), коммуникационная концепция (PRCA), коммуникативная компетентность (SPCC) и Международный университет Сараево. 